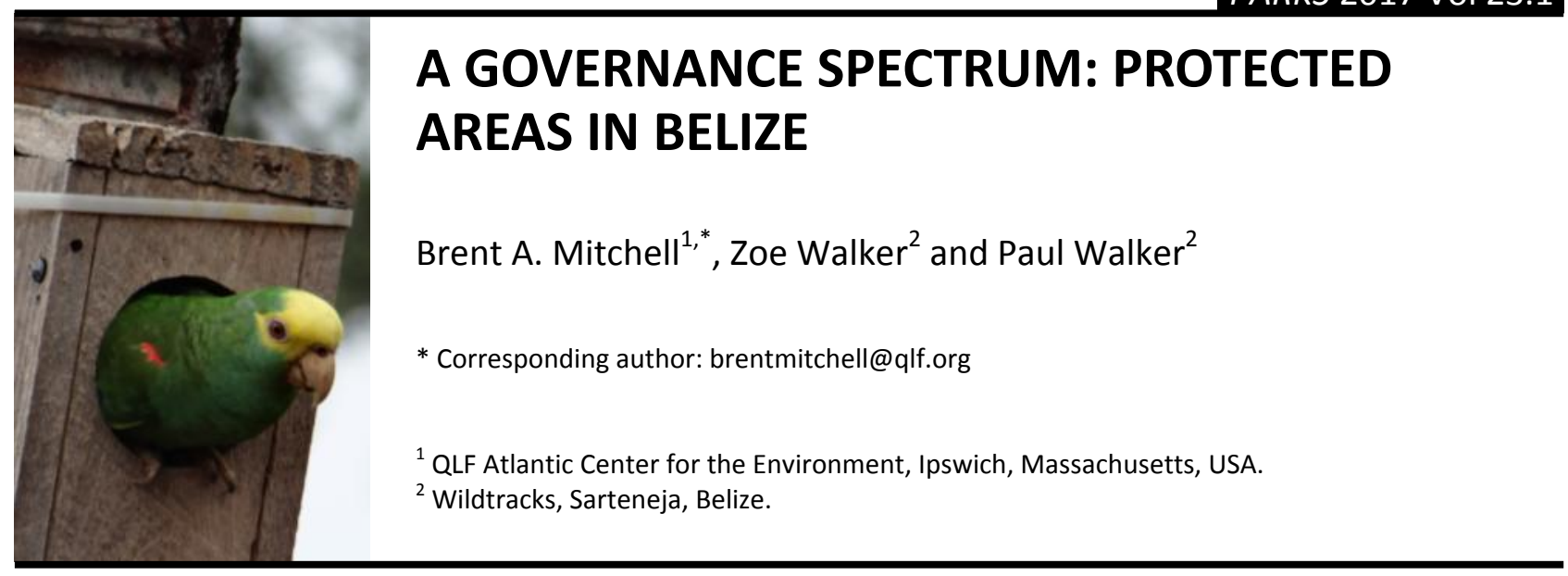

ABSTRACT

The size, scale and diversity of protected areas in Belize provide an informative case study of system management and governance that can offer a model for countries with expanding systems. The Belize National Protected Areas System is proportionately large for the size of the country, with terrestrial protected areas covering 36.6 per cent of the national territory and 19.8 per cent of the marine environment. The 108 sites in the National Protected Areas System exhibit the full spectrum of management categories and governance types recognized by IUCN. Though 85 per cent of terrestrial protected areas are national lands, only 43 per cent are managed directly by government agencies. The system overall is characterized by a heavy reliance on co-management, privately protected areas and ICCAs, in that order. Central government provides less than 18 per cent of the funding for management of the system. The diversity of actors in protected area management creates a dynamic, multivariate governance system, with different parties contributing to the debate to constantly refine management practices.

Key words: Belize, protected areas, system, governance, co-management, shared governance, privately protected areas, connectivity

Most countries are expanding their national protected area systems to meet biodiversity, nature conservation and other needs, whilst attempting to balance this with national development priorities. According to a 2013 IUCN global review of protected areas, "governance is the variable with greatest potential to affect coverage" and "governance is a main factor in determining the effectiveness and efficiency of management" (BorriniFeyerabend et al., 2013, xii). The governance of protected areas in countries with proportionately large national protected areas systems can inform other countries yet to expand.

Belize is one of only a dozen countries that have met Aichi Biodiversity Target 11 of the Convention of Biological Diversity (CBD) of the conservation of 17 per cent terrestrial and 10 per cent marine areas, respectively. Belize manages 36.6 per cent of its terrestrial area in protected areas and 19.8 per cent of its marine area (GoB, 2014). This paper describes the many governance structures Belize currently employs for these sites, outlines the history of the system and its governance, and highlights some of the current issues facing the national protected area system.

\section{GOVERNANCE AND MANAGEMENT}

Governance refers to all processes of governing, whether undertaken by a government, market or network, whether over a family, tribe, formal or informal organization or territory and whether through laws, norms, power or language (Bevir, 2013). It refers to the principles, policies and rules for decision-making, and these apply to protected areas as a dedicated land use of 'territory' for conservation. Most considerations of protected areas once centred on questions of management and management effectiveness. Since the World Parks Congress in 2003, however, there has been an increasing recognition of the importance of governance. Whilst governance and management are closely linked, they can be distinguished (BorriniFeyerabend et al., 2013). Governance sets the goals, objectives and policies for protected areas, the decisions that will influence the outcomes, and takes on accountability for those decisions, whilst management encompasses the methods and mechanisms to implement decisions taken through governance. Therefore, the governance structures that are in place and accepted at any given protected area can influence management. Governance is not new, of course, but the 
Table 1. Key facts about Belize and its protected areas. Based on an update of the Rationalization Report (Walker et al., 2013)

\begin{tabular}{|c|c|c|}
\hline Fact & Data & Notes \\
\hline Area (land/incl. sea in $\mathrm{km}^{2}$ ) & 22,966 & \\
\hline Population (\#) & 368,000 & \\
\hline Economic (GDP) & US\$1.807 billion & \\
\hline National Protected Areas (\#) & 108 & $\begin{array}{l}\text { Including Privately Protected Areas, Spawning } \\
\text { Aggregation Sites and Crown Bird Colonies }\end{array}$ \\
\hline Managed under the Forest Department & 51 & \\
\hline Managed under the Fisheries Department & 20 & Including 11 Spawning Aggregation Sites \\
\hline Managed under the Institute of Archaeology & 16 & \\
\hline Privately Protected Areas & 6 & $\begin{array}{l}\text { Including one community managed area of } \\
\text { private community lands }\end{array}$ \\
\hline Direct management by Government & 38 & \\
\hline Co-management & 28 & Not including Privately Protected Areas \\
\hline - NGO co-management & 16 & \\
\hline - Community co-management & 12 & \\
\hline - Long term Forest Licences & 10 & Based on 2010 agreements \\
\hline Spawning Aggregation Sites & 11 & $\begin{array}{l}\text { Protected areas where large densities of fish } \\
\text { regularly converge to reproduce }\end{array}$ \\
\hline Ramsar Sites & 2 & \\
\hline World Heritage Sites & 1 serial site ( 7 sites) & \\
\hline
\end{tabular}

increased focus on and understanding of governance is important to the effectiveness and efficiency of management. However, though IUCN first produced guidelines on protected area management categories in 1994, types of governance were not recognized until a revision published in 2008 (Dudley, 2008). IUCN recognizes four governance types:

- Government

- Shared governance

- Privately protected areas

- Indigenous and community conserved areas

The Belize protected area system demonstrates all of these types. As a small, democratic country with a diversity of protected area managers and authorities, limited financial resources and evolving governance structures, it presents a case study in these types, and gradations between them, that can provide a model for other national protected area system managers, policymakers and experts.

\section{EVOLUTION OF BELIZE PROTECTED AREAS}

Belize is a small, subtropical country approximately 280 $\mathrm{km}$ from north to south and $110 \mathrm{~km}$ wide, bordered by Mexico, Guatemala and the Caribbean Sea. It was originally occupied solely by the Maya people, until the arrival of Europeans in the $16^{\text {th }}-17^{\text {th }}$ centuries, and was a British colony from 1798 until 1981, when it gained independence. The country has three distinct physiographic regions: the flat northern lowlands, with a complex mosaic of lowland, semi-deciduous forests, savannahs, freshwater rivers and wetlands, with saltwater lagoons and mangroves along the coast; the southern coastal plain supporting tropical pine and broadleaf forest; and the Maya Mountains of granite, quarzites and shales. Seventy ecosystems have been identified within these broad categories (Salas \& Shal, 2015) The marine environment supports the second largest barrier reef in the world with a coastal lagoon of productive seagrass beds and patch reefs.

The environmental services of the protected area system are key to Belize's socio-economic health. The forested mountains provide clean water for the majority of communities in Belize, and the natural resources support the tourism industry, the primary foreign exchange earner in 2015 (Central Bank / BTB, 2016), and accounting for 34.8 per cent of employment (WTTC, 2016). Tourism in Belize is primarily natural- and cultural-resource based, with visitors focusing on the cayes, coastal communities and coral reef (particularly for its scenic beauty, snorkelling, diving and sport fishing), inland protected areas and Maya sites. 


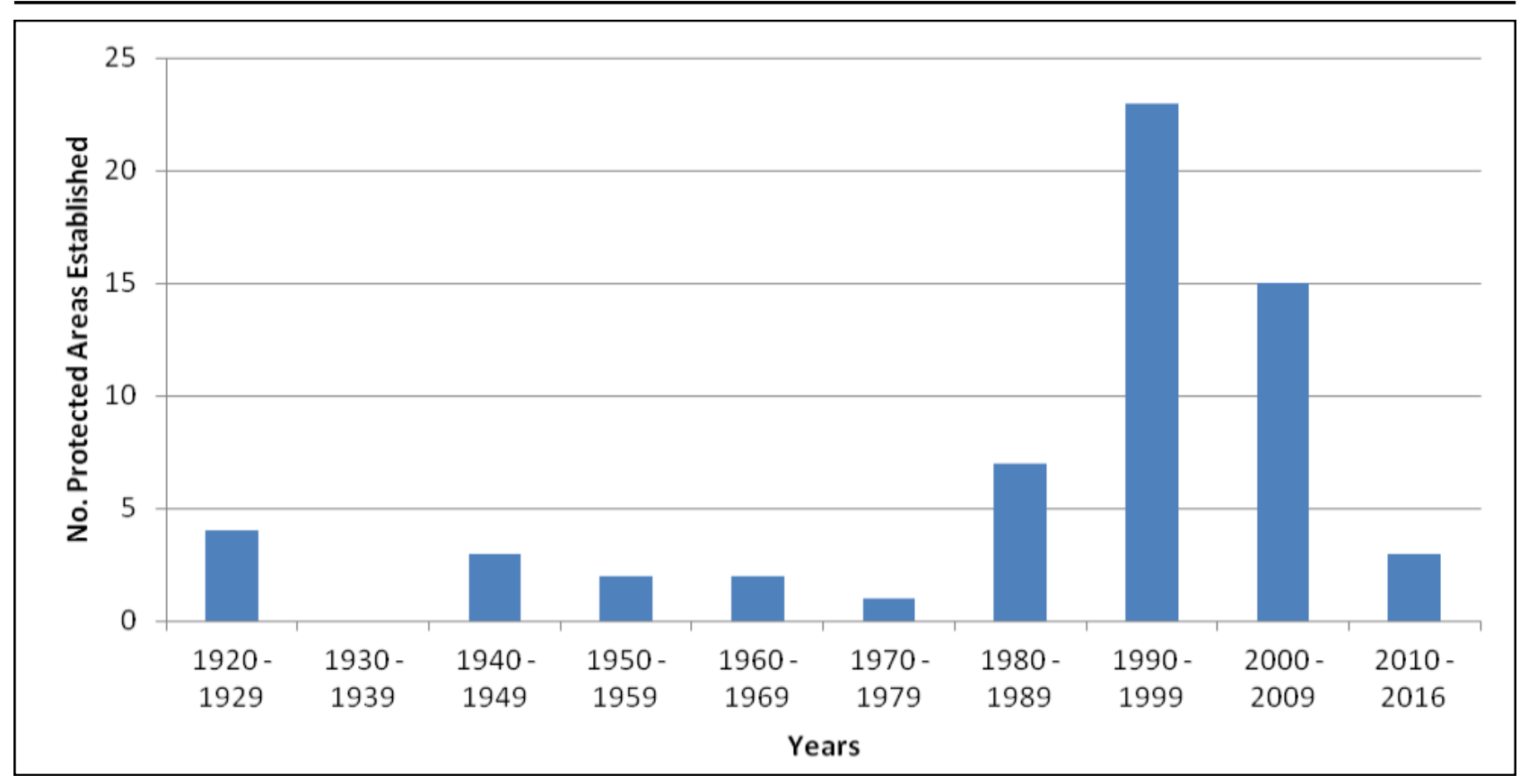

Figure 1: Trend of Protected Areas Establishment between 1920 and 2016

Changing threats have led to a shift in the reasons for the designation of protected areas, from the need to control unsustainable harvesting during the early days of the logging industry, to the need to balance the increased human footprint and associated habitat and species loss (Young, 2008). Reduced forest connectivity is impacting the viability of large-ranging species such as white-lipped peccary (Tayassu pecari), tourism infrastructure is rapidly removing littoral forest and coastline vegetation, and the increasing number of fishers and level of transboundary incursions are resulting in unsustainable levels of fishing.

The National Protected Areas System in Belize is the result of a long history of best-land-use surveys and natural resource protection that started with the Crown Land Ordinance in 1817, the first legal framework for control over land and natural resources (Young \& Horwich, 2007). This provided a mechanism for government-controlled lands to be set aside as forest reserves for improved management of forest resources primarily timber. Starting with the Silk Grass Forest Reserve in 1922, these were established for timber extraction (Zisman, 1996), and subsequently designated and managed under the Forest Ordinance of 1927.

The establishment of Half Moon Caye in 1928 as a Crown Reserve for the protection of its bird colony set Belize on the path as a conservation leader in the region, with the first reserve created specifically for the protection of wildlife. Generally, however, protected areas were for the management of the extraction of forest products until 1964, when attention turned to the need to protect areas for wildlife and for their intrinsic values. With the decline in the importance of logging to the national economy, recommendations were focused on a shift from forestry management to biodiversity protection. This led to the formation of the National Parks Commission in 1966, with the role of identifying and setting aside areas for the conservation of biodiversity. The establishment of Belize Audubon Society (BAS) in 1969, Belize's first nongovernmental organization, led to a strong private sector lobbying power focused on wildlife and wilderness protection and linked to international conservation partners.

In 1978, an FAO consultancy provided the first recommendations for the development of Belize's National Parks System: the 'Proposals for wildlife protection and national parks system legislation and the establishment of national parks and reserves' (Deshler, 1978). The National Parks System Act (1981) evolved from the FAO recommendations and provided the first enabling legislative framework for the development of the National Parks System, the pre-cursor to the National Protected Areas System that Belize has today. The mid to late 1980 s was a time of firsts. In 1984, the Community Baboon Sanctuary was established, the first community managed area of its type. In 1987 the first multi-use Marine Reserve, Hol Chan, was designated under the Fisheries (Amendment) Act of 1983 in recognition of its important role in supporting local fishers, and in Belize's fledgling tourism industry. In 1988-1989, the first two nationally recognized privately protected areas, Rio Bravo and Shipstern, were added to the protected areas system (though this was an informal recognition, and not supported by legislation until the revision of the National Protected Areas System Act in 2015). 


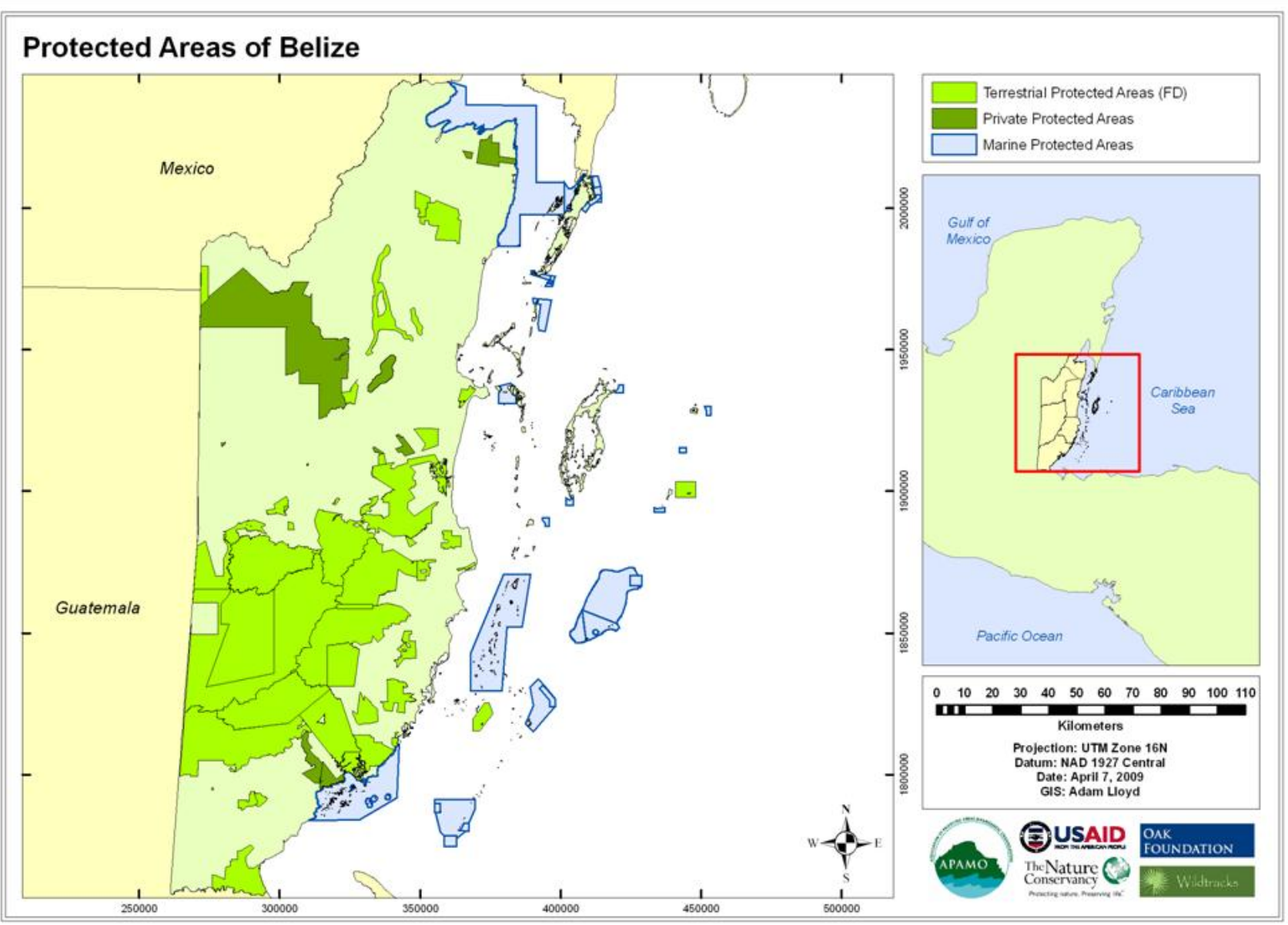

Figure 2: Protected Areas of Belize (Walker \& Walker, 2009)

In 1993, Belize took on international commitments with the ratification of the Convention on Biological Diversity for ecosystem coverage and species conservation. This was then followed in 1994-1995 by a comprehensive evaluation of the protected areas system, focused on identifying and addressing gaps to ensure that Belize met its national requirements for maintenance of biodiversity.

In the 1990 selize's national protected areas system was strengthened by a number of important national planning initiatives - the Natural Resource Management and Protection (NARMAP) project and Forest Planning and Management Project (FPMP). Another significant step was the establishment of two quasi-government agencies - the Coastal Zone Management Authority (CZMA) in 1998 for guiding activities in the coastal zone and the Protected Areas Conservation Trust (PACT) in 1996 as a funding mechanism for management of protected areas.

The Belize reef is the largest barrier reef complex in the Atlantic-Caribbean region, and the second largest in the world. In 1996 Belize signed the World Heritage Convention, inscribing the Belize Barrier Reef System World Heritage Site as a serial site of seven protected areas that provide representative examples of the outstanding reef system, reef types, reef connectivity, evolutionary processes and protection for threatened species. This resulted in the declaration of five additional protected areas, to ensure representative coverage of the unique aspects of the reefs of Belize.

In 1998, the Belize Manatee Recovery Plan was finalized under the CZMA, leading to the designation of three Wildlife Sanctuaries (Corozal Bay, Swallow Caye and Gales Point [Southern Lagoon]) over the next five years. They were designated specifically for their role in maintaining viable populations of manatee in Belize, as the stronghold for this species in the region.

As part of its commitments to the CBD, Belize developed its first National Biodiversity Strategy and Action Plan in 1998. Whilst this Plan was never officially endorsed, it was important in bringing government, non-government and community stakeholders together for the first time to discuss biodiversity management in Belize. In combination with the Northern Biological Corridor Project, it focused not only on the protected areas, but also on ecosystem connectivity, and encouraged communities to seek co-management of their natural resources towards maintenance of these critical links. 


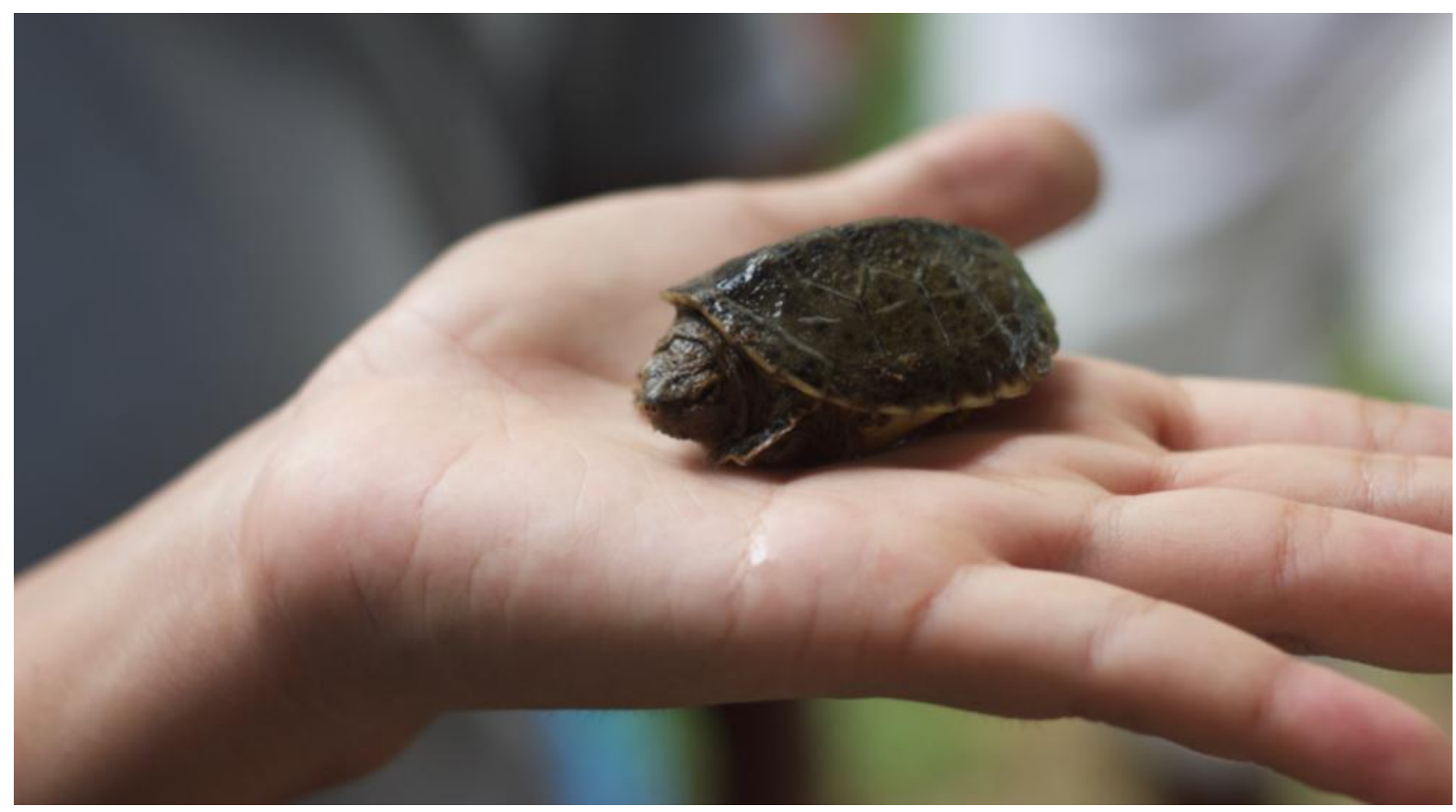

A baby Hicatee - Central American River Turtle (Dermatemys mawii) - hatched in captivity at TIDE's Private Protected Lands base station in May 2014 (C) Elmar Requena

These two initiatives created an environment of increased collaboration among community-based and non-governmental organizations. By 2005, an assessment of the National Protected Areas System (NPAS) demonstrated that it was considered to fulfil the majority of its functions, with little need for further additions to the system other than to improve forest connectivity (primarily through the integration of private lands in identified forest corridors into the system), and to provide coverage for a small number of underrepresented ecosystems - including the deep sea, mangroves and rivers.

\section{CURRENT STATUS}

A revision of the NPAS Plan in 2015, based on a national rationalization exercise, re-visited the NPAS categories. It was agreed to split the Wildlife category into twoone as non-extractive (Wildlife Sanctuary (1)), the other with potential for traditional use if supported by an approved sustainable use plan (Wildlife Sanctuary (2))in recognition of the importance of traditional natural resource use rights for local community-based users. The NPAS was considered to fulfil its roles in water catchment, watershed protection, storm protection and provision of other environment services. It was recognized, however, that with the increasing risks of hurricane impacts, increasing human footprint, pressures on the marine resources and changing weather patterns, the level of redundancy within the system is minimal, with the need to ensure retention of large areas and replication of ecosystems to guard against potentially non-reversible impacts, particularly with Belize being highlighted as at highest risk from climate change.

Belize currently has 36.6 per cent of its terrestrial area protected and 19.8 per cent of territorial waters under marine protective management (GoB, 2014), meeting and exceeding the CBD target (figure 2). However, for the marine environment, only 6.7 per cent is legislated replenishment zones with full protection against fishing activities. Belize is still working towards achieving the national target of ensuring that 10 per cent of all marine and coastal habitats within Belize's territorial waters are legally protected as non-extractive replenishment zones.

Over 90 per cent of Belize's 70 recognized ecosystems have greater than 10 per cent representation within the NPAS. 6o per cent have greater than 30 per cent representation within the NPAS, as per regional targets. As a result, the creation of new national terrestrial protected areas to strengthen ecosystem coverage is not considered critical, though realignments to improve the representation of rivers and riparian vegetation are recommended. The greatest gaps are in the coastal areas.

Current strengthening of the NPAS is focused on improving management effectiveness, ensuring the maintenance of ecosystem connectivity between protected forest nodes in the three identified key national corridors, and the realignment of marine protected area boundaries and zones to provide increased percentage of replenishment zone areas and the increased inclusion of deep water ecosystems. 
Table 2. Protected area governance types recognized in Belize (from National Protected Areas System Plan, 2015)

\begin{tabular}{|c|c|}
\hline Belize protected area governance types & Description \\
\hline $\begin{array}{l}\text { Government authority } \\
\text { Responsibility and accountability is founded on legislation } \\
\text { and rests with a government agency. Although management } \\
\text { may be exercised directly or be delegated, and consultation } \\
\text { or communication with concerned parties may be required, } \\
\text { government retains full ownership and control }\end{array}$ & $\begin{array}{l}\text { This is the mode of governance implicit under present } \\
\text { legislation but that has in many cases proved largely } \\
\text { ineffective due to chronic deficiencies in financial, human } \\
\text { and material resources. }\end{array}$ \\
\hline $\begin{array}{l}\text { Joint governance (co-management) } \\
\text { Authority, responsibility and accountability are shared among } \\
\text { a variety of concerned parties, which include government } \\
\text { agencies, and local communities, private landowners or other } \\
\text { stakeholders. The parties recognize the legitimacy of their } \\
\text { respective entitlements and choose or are required to } \\
\text { collaborate. }\end{array}$ & $\begin{array}{l}\text { This approach has been encouraged over the past two } \\
\text { decades, has proved effective, and has been the } \\
\text { preferred option for the development of the NPAS. By } \\
\text { 2012, } 32 \text { co-management agreements existed between } \\
\text { government agencies and some } 21 \text { civil society groups } \\
\text { (Walker \& Walker, 2013). A number of Forest Reserves } \\
\text { are also managed by logging concession holders under } \\
\text { long term ( } 20 \text { to } 40 \text { year) logging licenses that have strict } \\
\text { agreements that include protection of environmental } \\
\text { services and biodiversity }\end{array}$ \\
\hline $\begin{array}{l}\text { Private governance } \\
\text { Authority and responsibility rest with the landowners, who } \\
\text { may exercise it for profit (e.g., tourism businesses, resource } \\
\text { extraction) or not for profit (e.g., foundations, universities, } \\
\text { conservation NGOs). Usually, the landowners are fully } \\
\text { responsible for decision-making and their accountability to } \\
\text { the society at large is quite limited. }\end{array}$ & $\begin{array}{l}\text { Private governance does have its role where landowners } \\
\text { elect to use their holdings under a conservation } \\
\text { management regime, as an individual decision made in } \\
\text { their own interests. Unless the land is committed in trust } \\
\text { or under a covenant, however, there is the risk that the } \\
\text { land owners can decide to remove the land from the } \\
\text { National Protected Areas System }\end{array}$ \\
\hline $\begin{array}{l}\text { Community governance } \\
\text { Authority and responsibility for managing the natural } \\
\text { resources rest with the indigenous peoples and/or local } \\
\text { communities with customary and/or legal claims over the land } \\
\text { and natural resources. It is therefore analogous to private } \\
\text { governance and accountability to society at large usually } \\
\text { remains limited, although it is at times achieved in exchange } \\
\text { for recognized rights or economic incentives. }\end{array}$ & $\begin{array}{l}\text { This form of governance is usually associated with areas } \\
\text { (including those under partial private ownership) that are } \\
\text { collectively controlled or managed under traditional or } \\
\text { locally agreed rules, such as the Community Baboon } \\
\text { Sanctuary (considered a privately protected area) and the } \\
\text { Sarstoon Temash National Park. }\end{array}$ \\
\hline
\end{tabular}

\section{GOVERNANCE AND MANAGEMENT DIVERSITY}

Belize's National Protected Areas System is characterized by a heavy reliance on co-management partnerships, privately protected areas and ICCAs, in that order. Thus the System exhibits the full spectrum of management categories and governance types recognized by IUCN (Stolton et al., 2013).

The 2015 National Protected Areas Act replaces the National Park Act of 1981, presenting an updated framework for the System, articulating 13 categories of protected area and consolidating authorities under the Protected Areas Conservation Trust. The Act also establishes the National Protected Areas Advisory Council. Unlike the Protected Areas Conservation Trust, the Council is, with one exception, constituted of government officials.
Though criticized for a lack of consultation, the Act significantly strengthens the System by:

- integrating the legal requirement for stakeholder and community consultation and participation in the designation or revoking of protected areas, and the use of a standardised management planning process;

- providing a legal framework for integrating privately protected areas into the NPAS;

- facilitating the provision of "special management areas" for sites outside of the NPAS where critical management actions need to be put in place (for example, in the formation of corridors, or in managing the increasing watercraft activity on the Belize River delta, linked to increasing manatee mortality in this key manatee site); 


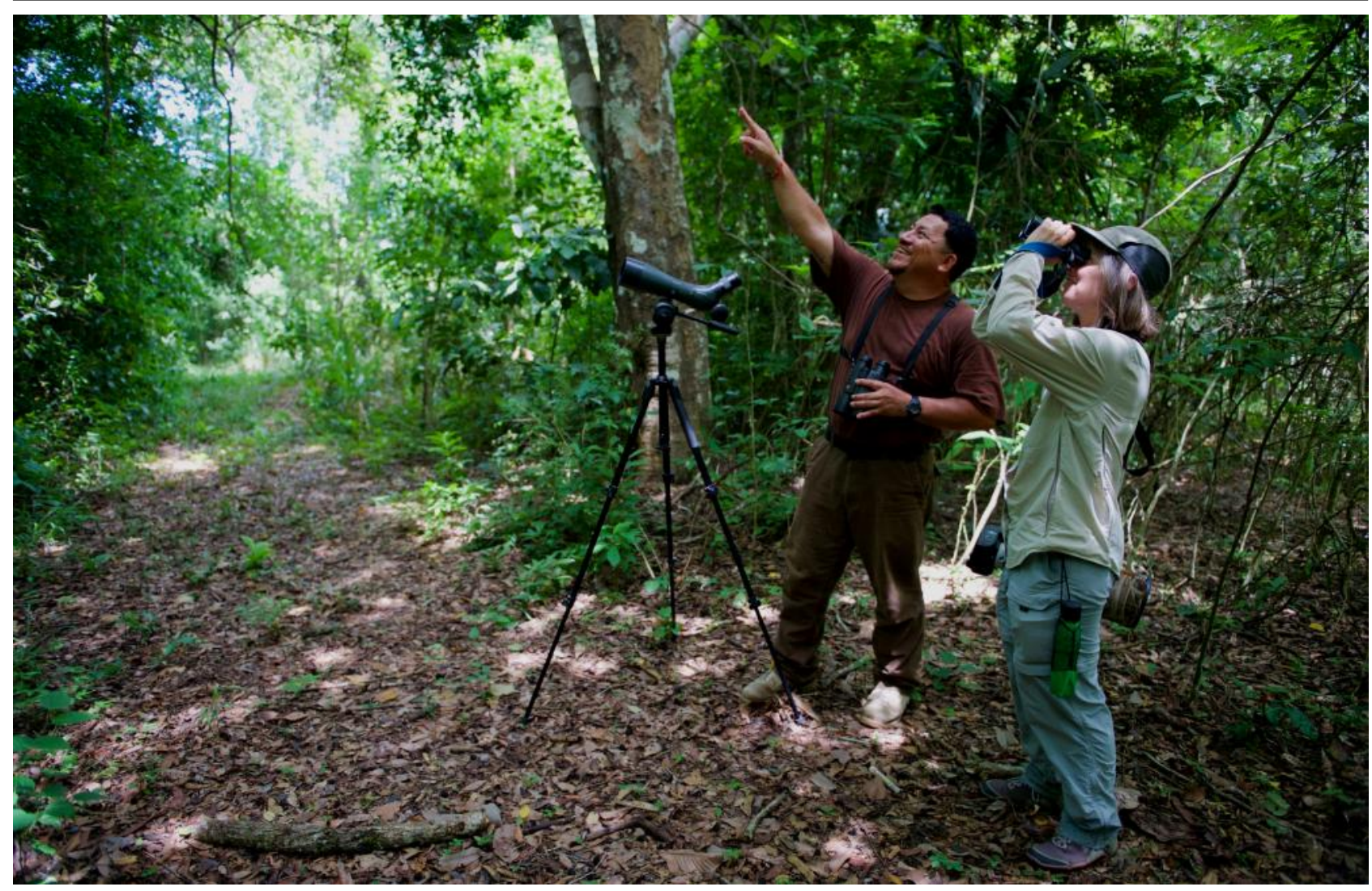

Birding at Rio Bravo Conservation and Management Area. At c. 105,000 ha. (nearly 5 per cent of Belize's land area) it is by far the largest privately protected area in the country $@$ Programme for Belize

- recognizing traditional use rights in areas where conflict exists between traditional use and the nonextractive designation of the protected area-if managed under an approved sustainable use management plan.

Individual protected area governance types recognized in Belize closely mirror those identified by the IUCN (Salas \& Shal , 2015).

\section{- Government Protected Areas}

Ninety-four per cent of protected areas in Belize are national lands administered by the Forest and Fisheries Department under the Ministry of Agriculture, Forestry, Fisheries and Sustainable Development, or by the Institute of Archaeology under the National Institute of Culture and History. However, only 22 per cent are managed directly by government agencies.

The Fisheries Department manages a number of marine reserves directly, including four of the seven units that constitute the Belize Barrier Reef System World Heritage Site. Whilst the Marine Reserves were legislated to include site level staff for basic management functions, those protected areas managed directly by the Forest Department do not have this provision, and therefore have limited financial resources and personnel available for direct management on the ground. The importance of the co-management partnerships with non-governmental organizations (NGOs), Community-Based Organization (CBOs) or long term logging concession holders therefore increases in this situation.

The NPAS also includes 16 Archaeological Reserves, the majority of which are Maya sites of antiquity. All are managed by the National Institute of Culture and History, which does not generally enter into comanagement agreements.

\section{- Co-management, or Shared Governance}

In Belize, the tradition of co-management is well established following the first co-management agreements with an NGO, the Belize Audubon Society (BAS), founded in 1969. By 1982 the Government of Belize and the BAS had developed agreements for joint management of six of the protected areas, in recognition of the limitations of the government's capacity for direct management of terrestrial protected areas. Today, 38 per cent of protected area units, including some of the largest protected areas in Belize, are managed by comanagement partners such as Belize Audubon Society under agreement with the government.

The Belize system, now codified in the National Protected Areas System Act, draws a sharp distinction between NGOs (non-governmental organizations) and 
CBOs (community based organizations). However, the distinction is somewhat arbitrary and based largely on scale. The distinction may be important in terms of the capacity to manage grants, develop management plans, and satisfy reporting requirements. But most NGOs are connected to their communities and many are derived from the growth and expansion of CBOs. The governing boards of the NGOs are nearly all Belizeans, as are the staff, and often include both technical experts and local community representation. Community and traditional user participation in governance of the protected area is generally through an Advisory Committee or similar structure. Governing boards of $\mathrm{CBO}$ co-management partners tend to be local community members.

Thirteen protected areas are managed by CBOs, twelve of these through formal or informal co-management agreements with the government. The thirteenth, the Community Baboon Sanctuary (CBS), differs in that the protected area is based on private lands. The CBS was founded in 1985 as a community conservation initiative to ensure the long-term survival of Yucatan black howler monkeys (Alouatta pigra) - known locally as 'baboons'. The monkeys are also a tourism attraction, and thus an important resource for local communities. The Sanctuary is comprised of a series of land-use agreements under which private landowners agree to leave corridors of tree connectivity across their lands to allow howler monkeys to feed and travel.

In terms of the IUCN governance typology, the CBS inhabits a blurred boundary between a privately protected area and indigenous peoples' and community conserved territories and areas (ICCAs). Private landowners agree to participate but do so as part of a community effort, thus the Sanctuary might be considered a hybrid of the two. This is an excellent example of gradation among the protected area governance types. In practice the types are not always as distinct as they appear in theory; some protected areas exhibit characteristics of more than one governance type.

\section{- Indigenous and Community Conserved Areas}

Of the four governance types, ICCAs are the least well represented in Belize. As noted above, twelve community groups manage protected areas (some of them indigenous communities), under formal or informal agreement with government, and based on nationally held lands within the NPAS, defined under statutory instrument. The recent revision of the NPAS Act opens the way for establishment of community protected lands through Special Management Areas, when these lands are able to contribute towards the NPAS, such as formation of key corridors or protection of key species.

\section{- Privately Protected Areas}

Reflecting global trends, privately protected areas (PPAs) play an important and growing role in the NPAS (Stolton et al., 2014). Currently six PPAs are recognized by government (though a further two are reported to the WDPA - these two are no longer considered part of the system). In 2013, 17 other private areas were identified for future recognition as PPAs (Walker \& Walker, 2013). National recognition of PPAs is based on an evaluation of their role within the NPAS, improving key connectivity in recognised priority national corridor routes, protecting important environmental services, or protection of critical habitat / species. Two of the larger protected areas in Belize are PPAs, the c. 105,000 ha Rio Bravo Conservation and Management Area and 8,226 ha Shipstern Conservation and Management Area.

Despite the important current and potential role of PPAs in the national system private conservation faces many challenges in Belize. IUCN guidance on privately protected areas calls for "...long-term intent to conservation. Long-term here should be at least 25 years, though the intent should be conservation 'in perpetuity', and safeguards put in place to ensure conservation objectives persist even if ownership changes." (Stolton et al., 2014, p x). Only three PPAs have secure long-term protection (Shipstern, Rio Bravo and TIDE Block 147). The other existing PPAs satisfy IUCN definitions by having long-term intent for conservation but there have been limited legal or institutional mechanisms in place to secure that intent. A perennial concern with unsecured PPAs is that land use may change when the private land ownership changes. For some PPAs, intent was insufficient, with two of the 17 candidate PPAs already largely lost to land conversion.

Currently there are no clear, tangible incentives for private landowners to manage their land for conservation. PPAs (like conservation on the larger landscape) face a challenge in a perverse tax incentive to develop land. In an attempt to discourage speculation, Belize levies an "undeveloped land tax" whereby undeveloped land is taxed at a higher rate than land converted to agriculture or otherwise developed. In at least one instance the owner of 95,00o acres of forested land (Corozal Timber) within a critical national corridor area (the Balam Jungle Estate) sold off 25 per cent of the area after annual taxes increased four-fold, resulting in the immediate clearance of 25,000 acres for agriculture.

These losses to conservation, and particularly to connectivity, vividly underscore the need to secure in the long term private conservation where it occurs, and their recent occurrences indicate a need for urgent action by 


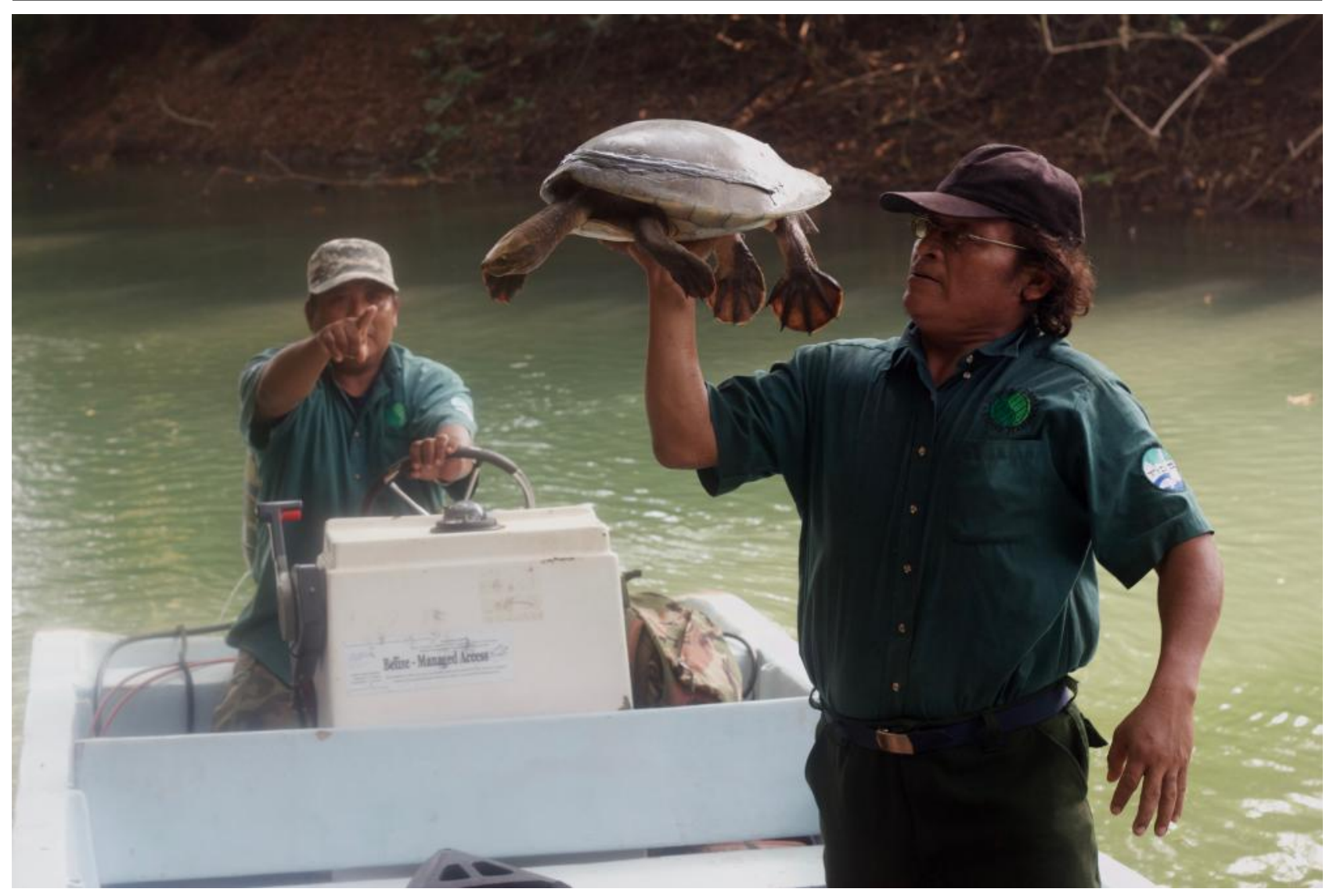

Staff of the Toledo Institute for Development and Environment inspect a Hicatee turtle found on the Rio Grande River in TIDE's Private Protected Lands in June 2014 @ Karena Mahung

the government to establish a system to recognize, monitor and incentivize PPAs. For Rio Bravo Conservation and Management Area and Shipstern Conservation and Management Area, this has been resolved by placing the land in trust to the people of Belize. More recently, the revised NPAS Act provides a legislative framework for the recognition of PPAs in the NPAS (GoB, 2015b).

In the face of these challenges and issues, the Belize Association of PPAs, representing land owners wishing to commit lands to conservation, is working to further realize the potential for PPAs in the country, particularly under the revised NPAS legislation.

\section{- Complexity: Resilient or Inefficient?}

In the absence of checks and balances in central government, the diversity of actors (government agencies, NGOs, community groups and logging concession holders) in protected areas management helps to create opportunities for course corrections, with different parties participating directly in national initiatives to refine management practice. The involvement of civil society acts as a balance in a system vulnerable to political whim. The greatest weakness in the NPAS has, in the past, been ministerial discretion.
Legally, the Minister responsible for protected areas has the power to de-gazette a protected area with the stroke of a pen. This sweeping authority has, to some extent, been mitigated as any de-gazettement must now go through a consultation process.

The Government of Belize is limited financially, and does not prioritize investment in the NPAS, despite this being the foundation for its tourism industry. It therefore relies heavily on its co-management partners (and increasingly PPAs and ICCAs) for locating the financial resources required for effective management. However, such assistance from civil society can lead to an abdication by government of its role in managing protected areas, and lead to an under-appreciation of the value of the National Protected Areas System - not only by government, but also by the Belizean people.

\section{MANAGEMENT EFFECTIVENESS OF THE NPAS}

An assessment in 2009 looked at management effectiveness across the different management regimes (Walker et al., 2009). Seven management regimes were recognized under the assessment, including management by long term logging concession holders through forest licences (see figure 3), defined by the structure of the different governance partnerships, from direct 
Protected area management regimes

Average score

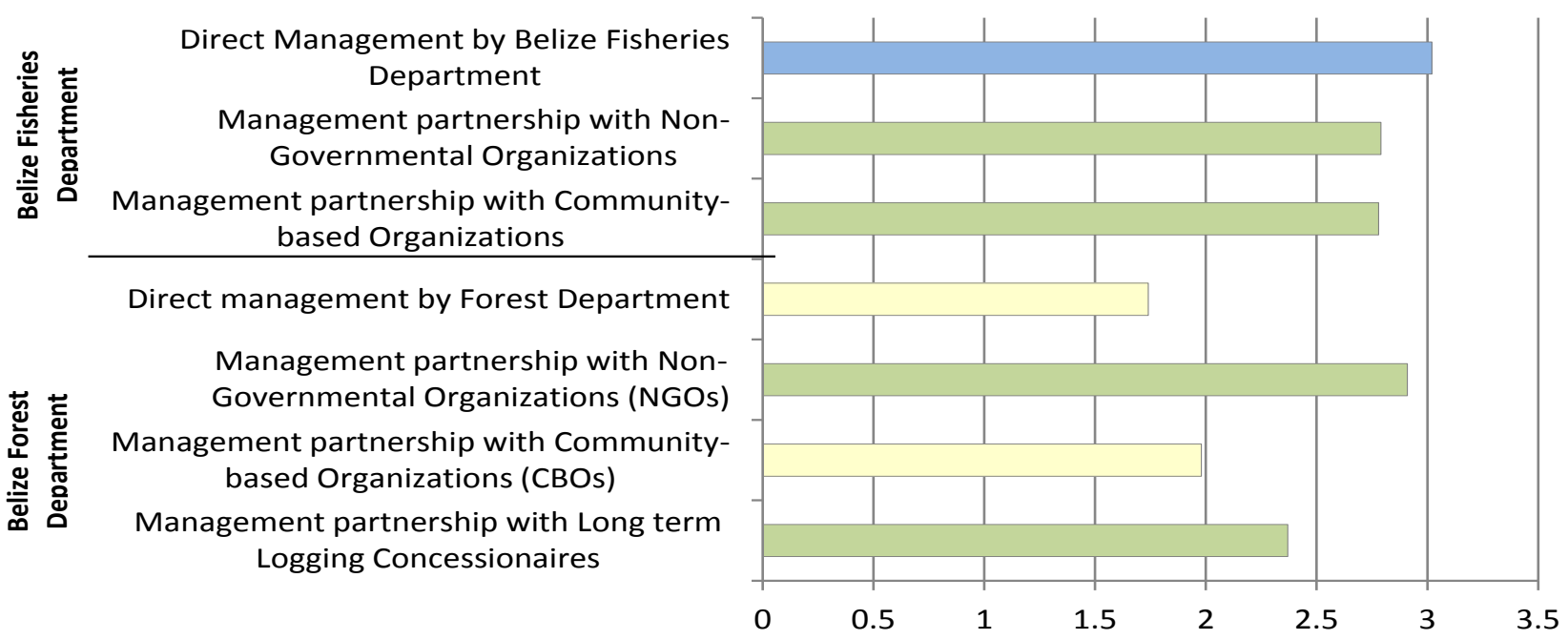

Key

\begin{tabular}{l|l|l||l|} 
Poor: $\leq 1.00$ & $\begin{array}{l}\text { Fair: }>1.00- \\
2.00\end{array}$ & $\begin{array}{l}\text { Moderate: } \\
>2.00-3.00\end{array}$ & Very Good: $>3.00$ \\
\hline
\end{tabular}

Figure 3: Management effectiveness based on governance and management regimes (Walker \& Walker, 2009)

governance and management by government entities to co-management partnerships with NGOs and CBOs and logging concession agreements. The outputs demonstrated that:

- Protected areas governed by and managed directly under the Fisheries Department had the highest average management effectiveness score; 3.02 out of a possible score of 4.00 (75.4 per cent), rating as VERY GOOD, reflecting the government investment in staff, equipment and operational costs.

- Protected areas governed by and managed directly under the Forest Department had the lowest management effectiveness score; 1.74 out of 4.00 (43.4 per cent), rating as FAIR, reflecting the limited investment from central government.

- Protected areas under co-management agreements between NGOs/CBOs and the Forest Department differ greatly. Management effectiveness of protected areas under NGO governance and co-management average at the higher end of MODERATE, with a score of 2.91 out of 4.00 (71.8 per cent). Comanagement with $\mathrm{CBOs}$ rates as FAIR, with an average score of 1.98 (49.4 per cent).

- Protected areas managed through co-management agreements between NGOs/CBOs and the Fisheries Department rated as MODERATE in their level of management effectiveness, averaging a score of approximately 2.79 out of 4.00 (69.7 per cent). There was little difference between NGO co-management partnerships (which scored 2.79) and that with a CBO (2.78), reflecting the level of support co-management partners receive from the Fisheries Department.
It should be noted that, based on site specific assessments, there has been a significant improvement in the effectiveness of co-management agencies across the NPAS since the 2010 assessment, but there has not yet been an updated national assessment.

\section{DISCUSSION}

- System level management and connectivity

Despite being a small country with limited human and financial resources for investment in protected areas, Belize has a NPAS of over 100 individual sites, managed under three different departments across two different ministries. Managing individual conservation areas of this number is challenging and can be inefficient, leading to repetition and overlap, with no maximizing through efficiencies of scale. The National Protected Areas Policy and System Plan (2005) recommended the simplification of the existing protected areas system through consolidating adjacent protected areas with similar landscape or seascape features, socio-economic contexts, and conservation threats into larger, system-level management units, with increased coordination and collaboration between site-level management agencies. This creates a smaller number of system level units that are more firmly integrated into the landscape/seascape context, incorporating biological corridors and facilitating a more coordinated management regime towards unified goals and visions.

These system-level units are comprised of geographically grouped protected areas within the same landscape or seascape that share similar stakeholders and impacts. To 


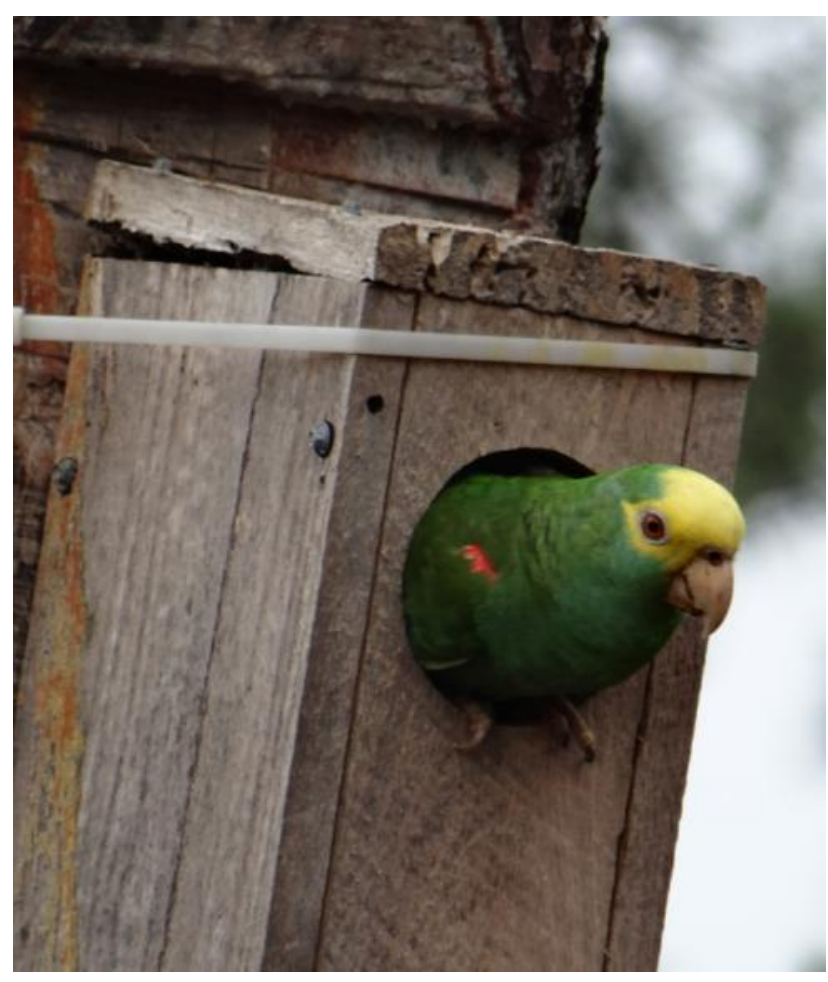

Yellow-headed parrot (Amazona oratrix) in an artificial nest box taken at Payne's Creek National Park March 2013 ㅇ Andrew Williams

date, four have been established, using conservation action planning (CAP) as a framework to improve communication and collaboration within the units. Three of these are in the southern half of Belize: the Maya Mountains Massif, Maya Mountains Marine Corridor and Southern Belize Reef Complex. The fourth, and most recent, the Northern Belize Coastal Complex, is in the north. These system level units have varying degrees of success, based on the level of buy-in by the management agencies (as they require an effort to overcome turfprotectionism) but provide an opportunity for increased management support and cost-effectiveness within a landscape/seascape.

The Northern Belize Coastal Complex (NBCC) demonstrates the river-to-reef seascape role of the system-level management units. The six protected areas that lie within the NBCC are managed under different legislative designations and different governance and management regimes. Corozal Bay Wildlife Sanctuary (CBWS) protects the Belize waters of the largest transboundary estuarine system flowing into the Mesoamerican reef. CBWS was originally established for its role in protection of the endangered Antillean manatee (Trichechus manatus), as well as for its service as a fish nursery area. CBWS is managed by a CBO, the Sarteneja Alliance for Conservation and Development, with site-specific conservation targets focused on improving the viability of manatees, mangroves and estuarine species. Bacalar Chico, Hol Chan and Caye
Caulker Marine Reserves are managed directly by the Belize Fisheries Department, with conservation targets focused on reef health and reef species. Conservation planning at system level, however, brings the management of the river to reef seascape into sharper focus, with system-level management strategies for increased reef health being integrated into management of the estuarine system, and vice versa.

The planning process for these system-level management units brings site-level management personnel together, providing space and a framework for protected area managers to meet to discuss threats, impacts and conservation strategies beyond their respective site-level protected area boundaries. This leads to improved coordination and collaboration between protected areas towards system-level goals, improving effectiveness, reducing overlap and increasing cost effectiveness. Strategies such as joint patrols, sharing of capacity building opportunities, standardization of biodiversity monitoring over the system and sharing implementation of education and awareness strategies in stakeholder communities all increase effectiveness of the system, as does the recognition of the value of non-protected sea within the seascape, its role in maintaining marine connectivity and ecosystem services.

\section{- Viability in the long term}

With the exception of the forest and marine reserves which are managed primarily for extracted resources, protected areas have developed in Belize largely in a reactionary way, in response to the threats of the day. And although great progress has been made, the system is not yet sufficiently respected by government and the Belize people to maintain integrity against many looming threats that are proximate and inevitable. Among these are:

- Population growth and concomitant demands on land use. Though population density is relatively low in Belize it is not heavily urbanized; the total population of Belize has doubled in 30 years and is projected to treble again by 2050 .

- High poverty levels.

- Climate change - including sea level rise.

The country is not yet making strategic investments for the long term (50-100 years) to minimize erosion of the conservation value of its protected areas, and these and other threats will increase pressure to allow greater use and conversion of protected areas.

The NPAS Plan (Salas \& Shal, 2015) identifies three main barriers to successful implementation: 


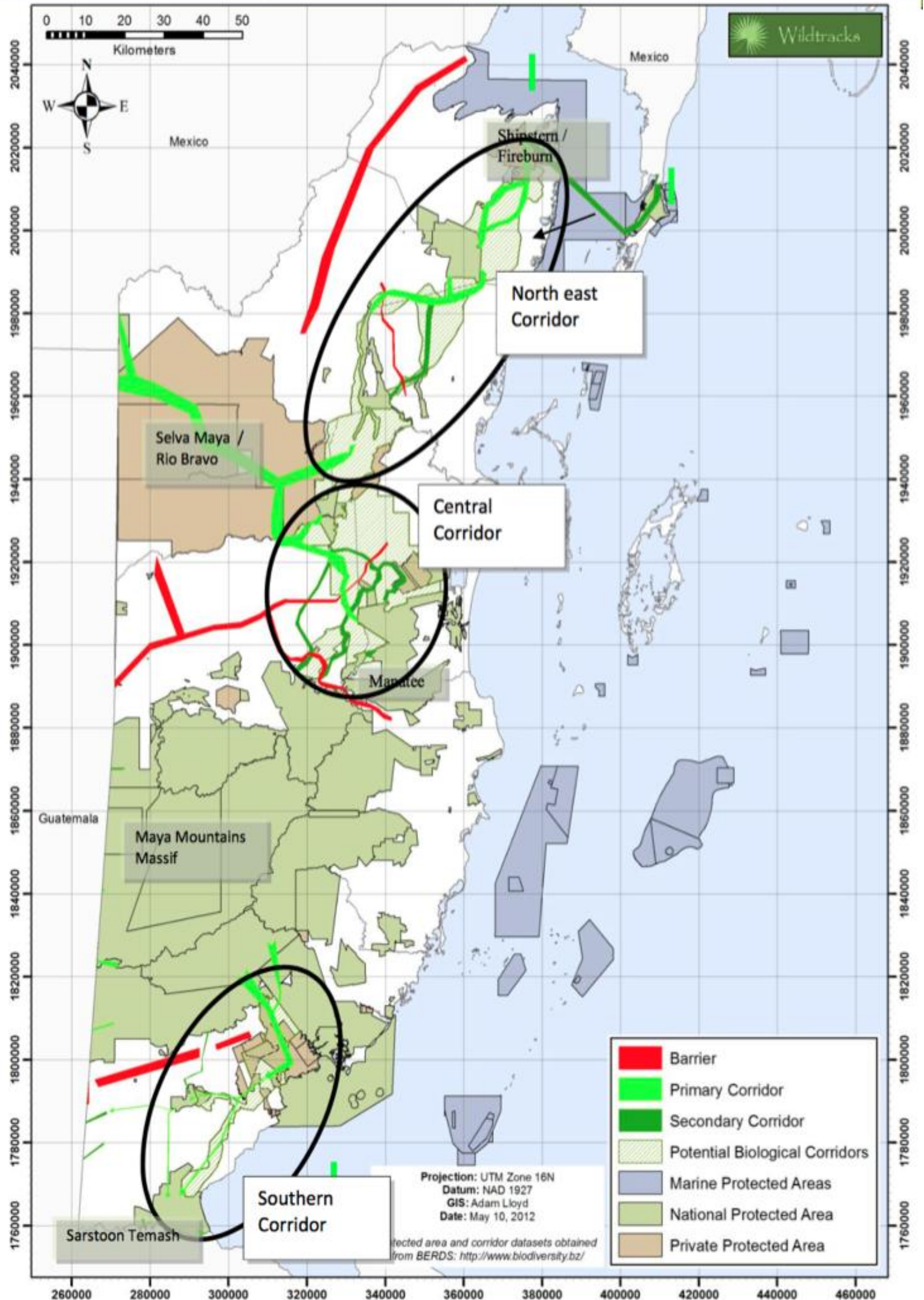

Figure 4: Identified Nodes and Primary Biological Corridor Routes (Walker \& Walker, 2013 ) 
The NPAS is currently fragmented, not cost-effective and not financially sustainable;

- Biodiversity within protected areas is increasingly isolated as historically connecting landscapes are transformed while surrounding communities remain indifferent, or even opposed, to protected areas and their conservation goals; and

- PPAs are isolated from the broader NPAS, with few incentives or mechanisms for their establishment or effective management for conservation.

Conservation depends not only on protection but also on connection (Lovejoy \& Wilson, 2015). Plants and flightless animals require connectivity of habitats in order to move, both for their natural life cycles and in response to climate change. According to the IUCN, a connectivity conservation area is "actively, effectively and equitably governed and managed to ensure that viable populations of species are able to survive, evolve, move and interconnect within and between systems of protected areas and other effective area based conservation areas" (Worboys et al., 2016, p17). However, in recognition of this issue, there are currently two initiatives underway to secure key corridor connectivity (figure 4).

\section{FINANCE AS MEANS AND TOOL}

The NPAS is supported through a variety of funding mechanisms including national allocations towards the ministries responsible for natural resource management, grants from the Protected Areas Conservation Trust (PACT), Debt-for-Nature agreements, revenue generated directly by the protected areas themselves, and funds leveraged by protected area co-management agencies. There is a strong reliance on bilateral and multi-lateral international funding.

External funding for protected areas in Belize, sourced by the co-management partners, has two sides. On the one hand, it is very positive in facilitating management of protected areas that might not happen otherwise. On the negative side, it reduces the necessity for the Government of Belize to recognize and begin to account for the benefits protected areas provide, including 1) disaster risk reduction (reduced flooding, landslides, erosion, etc); 2) basis for tourism, central to the economy; 3) water security; etc.

PACT is a quasi-government entity (by law nongovernment representatives serve as board members in a slight minority to government officials) and as such also receives grants from external sources (GoB, 2015a). It is the primary national financial sustainability mechanism for support of the NPAS. One of the NPAS financial sustainability mechanisms focuses on fees associated with tourism. Thereby, 45 per cent of PACT's income was received from a Conservation Fee, levied on departing visitors to Belize and 49 per cent from the commission levied on cruise ship passengers. The remaining 6 per cent is through interest and other income sources (including investments and donations from agencies, corporations and interested individuals). These funds are then distributed to protected area managers of all governance regimes, currently on a competitive basis. The role of PACT is being greatly expanded following the revision of the NPAS in 2015 to include strategic planning for the system, monitoring and evaluation, and review of individual management plans for each protected area, duties previously performed by the Forest and Fisheries departments.

Belize is highly dependent on its natural and cultural resources. Tourism is the main earner of foreign currency and is based largely on nature and culture. Agriculture is dependent on water supplied by protected watersheds, and fisheries on both no-take zones and limited run-off from rivers. As the climate changes, disaster risk reduction becomes increasingly important. (For example, in 2008, Hurricane Arthur raised awareness when flooding destroyed the Kendal Bridge, requiring a US\$5.45 million replacement, a large sum in the tiny Belizean economy). The revenue system, however, does not recognize the value of conservation for its current use in providing ecological services nor the cost to government of providing services to developed areas. This is not helped by the fact that a calculation of the value of Belize protected areas has not yet been made or accepted. However, the Biodiversity Finance Initiative (BIOFIN) is starting this work. The programme has identified that current sources of protected area finance include central government allocations (US\$1.9 million), extra budgetary funding (US\$2.4 million), local fees and concessions (US\$3.8 million) and grants and other sources (US\$2.6 million). BIOFIN however, estimate that the funding needs of the NPAS in Belize are expected to double over the coming decade (UNEP-WCMC \& IUCN, 2016). Understanding the full value of the NPAS should provide a strong argument for increased funding.

\section{CONCLUSION}

Belize can boast a large and representative protected area system with reasonably good legislation and improving enforcement. The size, scale and diversity in Belize combine for an instructive case study of protected area system management and governance. Belize is a small country in both land area and human population. It is 


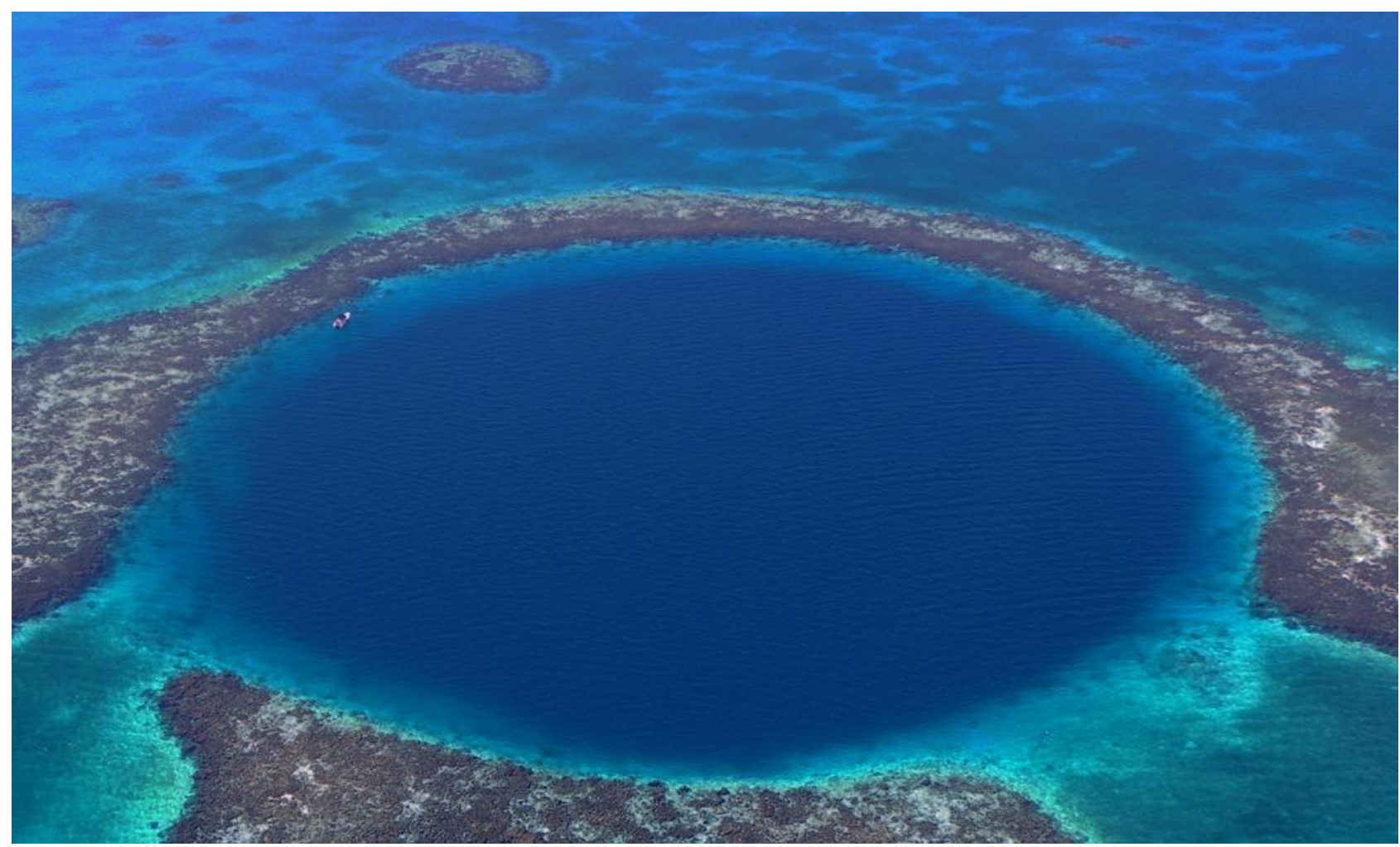

Blue Hole Natural Monument is managed by the Belize Audubon Society under a co-management agreement with the Belize Forest Department. The iconic tourist attraction is one of seven sites in the Belize Barrier Reef Reserve System World Heritage Site (c) Belize Audubon Society

quite different from its neighbours Guatemala and Mexico in political structure, economic system and colonial history. In many ways it is an island in its region. Though a small country its NPAS is impressive and proportionally very large; in area it is second only to Nicaragua in de jure protected area in Mesoamerica. As the national system nears completion any expansion is likely to include novel forms of management and governance. The growing diversity of protected area governance types and finance systems may provide lessons for the development of more complex protected area systems in larger countries. But old and new threats encroach on the integrity of the system, and several large, important and intact privately-held natural areas have been lost to land conversion in the past two years.

The NPAS exemplifies all types of governance regime as recognized by IUCN, with heavy reliance on comanagement, or shared governance, and increasing dependence on PPAs and community managed areas to fill in the gaps. The many different actors with direct management responsibility for protected areas bring diversity to decision-making and greatly increase the capacity for practical, on-the-ground management. This diversity of governance also helps to counteract the issues confronting system management, including: lack of human capital and financial resources; dependence on external funding; and flaws in the taxation system creating perverse incentives to clear land.
Protected area management is a huge challenge in Belize, but technical capacity within government is increasing. The full range of governance types, government agencies, and civil society managers operating in Belize, and their connection to a national PA system - all through the six system-level areas, once fully established - will create a web of interdependence. This web should help individual sites in the system grow to the next level of integration with each other and other land use interests at the larger landscape and seascape scale.

\section{ABOUT THE AUTHORS}

Brent Mitchell is Senior Vice President of the Quebec Labrador Foundation / Atlantic Center for the Environment, advancing conservation through international exchange, facilitation and technical assistance in over 50 countries. Brent is a founding partner in the National Park Service Stewardship Institute; chairs a specialist group on privately protected areas within IUCN's World Commission on Protected Areas; and is a past president of the George Wright Society. QLF has conducted training, exchange and assistance projects with partners in Belize for more than two decades.

Zoe Walker graduated from University of Leeds with a degree in Ecology. She is a co-director of Wildtracks and a leader in the field of conservation planning in Belize. She works with both government and non-government 
agencies towards strengthening the national protected areas system, as well as ecosystem and wildlife conservation and management. A leader in inclusive participatory planning and assessments, she has led many national and site level conservation planning initiatives, resulting in outputs ranging from protected area management plans for more than 20 of Belize's protected areas to Belize's 5th National Report to the Convention on Biological Diversity.

Paul Walker graduated from the University of Leeds in the UK with a degree in Zoology. He is co-director of Wildtracks, and works with conservation organizations in Belize to improve ecosystem and species conservation. $\mathrm{He}$ directs the wildlife rehabilitation activities and subsequent releases. Previous wildlife experience includes wildlife rehabilitation from an early age, care of sanctuary primates in the UK, involvement in the initial rehabilitation of chimpanzees in Spain and planning for their release in the Ivory Coast, and postgraduate research on tropical amphibian ecology. Research publications spread from amphibian ecology, species assessments, to forest structure and carbon storage, biodiversity and protected area planning.

\section{REFERENCES}

Bevir, M. (2013). Governance: A very short introduction. Oxford, UK: Oxford University Press.

BTTB (2016) Belize Travel 7 Tourism Statistics Digest 2015. Belize Travel and Tourism Board.

Borrini-Feyerabend, G., Dudley, N., Jaeger, T., Lassen, B., Pathak Broome, N., Phillips, A. and Sandwith, T. (2013). Governance of Protected Areas: From understanding to action. Best Practice Protected Area Guidelines Series No. 20, Gland, Switzerland: IUCN.

Deshler, W.O. (1978) Forestry development, Belize. Proposals for wildlife protection and national parks system legislation and the establishment of national parks and reserves. Report No. FAO-FO-BZE/75/008. FAO

Dudley, N. (ed) (2008). Guidelines for Applying Protected Area Management Categories. Gland, Switzerland: IUCN.

Government of Belize (2014). National Stocktaking and Target Setting for Biodiversity Planning in Belize (2014). Forest Department, Ministry of Forestry, Fisheries and Sustainable Development, Belmopan.
Government of Belize (2015a). National Protected Areas System Act.

Government of Belize (2015b). National Protected Areas Conservation Trust (Amendment) Act.

Lovejoy. T.E. and Wilson, E.O. (2015). The Opinion Pages: A Mojave Solar Project in the Bighorns Way, The New York Times, 12 September 2015, New York.

Salas, O. and Shal, V. (eds) (2015). National Protected Areas System Plan, Revised Edition. Ministry of Forestry, Fisheries and Sustainable Development, Government of Belize.

Stolton, S., Shadie, P. and Dudley, N. (2013). IUCN WCPA Best Practice Guidance on Recognising Protected Areas and Assigning Management Categories and Governance Types, Best Practice Protected Area Guidelines Series No. 21. Gland, Switzerland: IUCN.

Stolton, S., Redford, K. H. and Dudley, N. (2014). The Futures of Privately Protected Areas. Gland, Switzerland: IUCN.

UNEP-WCMC and IUCN (2016). Protected Planet Report 2016. Cambridge, UK and Gland, Switzerland: UNEP-WCMC and IUCN.

Walker, Z. and Walker, P. (2009). The Status of Protected Areas in Belize - Report on Management Effectiveness. Produced for APAMO and Government of Belize.

Walker, Z. and Walker, P. (2013). Rationalization Exercise of the Belize National Protected Areas System. Belize Forest Department, Ministry of Forest, Fisheries and Sustainable Development.

Worboys, G.L., Ament, R., Day, J.C., Lausche, B., Locke, H., McClure, M., Peterson, C.H., Pittock, J., Tabor, G. and Woodley, S. (2016). Advanced Draft, Connectivity Conservation Guidelines: Definition, Types, Selection Criteria and Governance. Gland, Switzerland: IUCN.

WTTC. (2016) Economic Impact 2016 Belize. World Travel \& Tourism Council

Young, C. (2008). Belize's Ecosystems: Threats and Challenges to Conservation in Belize. Tropical Conservation Science 1 (1):18-33. Available online: tropicalconservationscience.org

Young, C. and Horwich, R. (2007). History of Protected Areas Designation, Co-management and Community Participation in Belize. In: B. Balboni and J. Palacio (eds) Taking Stock: Belize at 25 years of Independence, Volume 1, pp. 123-145. Belize: Cubola Productions.

Zisman, S. (1996). Directory of Belizean Protected Areas and Sites of Nature Conservation Interest. 2nd ed. WWF-US/ NARMAP.

\section{RESUMEN}

El tamaño, la escala y la diversidad de las áreas protegidas en Belice proporcionan un estudio de caso informativo sobre la gestión y gobernanza del sistema que puede ofrecer un modelo para los países con sistemas en expansión. El Sistema Nacional de Áreas Protegidas de Belice es proporcionalmente extenso para el tamaño del país, con áreas protegidas terrestres que cubren el $36,6 \%$ del territorio nacional y el 19,8 por ciento del medio marino. Los 108 sitios comprendidos en el Sistema exhiben el espectro completo de categorías de gestión y tipos de gobernanza reconocidos por la UICN. Aunque el 85 por ciento de las áreas protegidas terrestres son tierras nacionales, solo el 43 por ciento de ellas son administradas directamente por dependencias gubernamentales. El sistema en general se caracteriza por una fuerte dependencia de la cogestión, de las áreas protegidas privadas y de los Territorios y Áreas Conservadas por Pueblo Indígenas y Comunidades Locales (ICCA), en ese orden. El gobierno central provee menos del 18 por ciento de la 
financiación para la gestión del sistema. La diversidad de actores en la gestión de áreas protegidas crea un sistema de gobernanza dinámico y multivariado, en el que los diferentes grupos interesados mantienen una presencia destacada en el debate para perfeccionar constantemente las prácticas de gestión.

\section{RÉSUMÉ}

L'ampleur, l'échelle et la diversité des aires protégées au Belize proposent un riche cas d'école sur la gestion et la gouvernance, qui peut servir de modèle pour des pays dont les aires protégées sont en expansion. Le système national des aires protégées du Belize occupe un territoire proportionnellement grand pour la taille du pays, couvrant 36,6\% du territoire terrestre et 19,8\% du milieu marin. Les 108 aires protégées présentent l'éventail complet des catégories de gestion et des types de gouvernance reconnus par l'UICN. Bien que 85\% des aires protégées terrestres soient des terres nationales, seulement $43 \%$ sont gérées directement par des organismes gouvernementaux. Le système dans son ensemble se caractérise par une forte dépendance envers la cogestion, les aires protégées privées et les APACs, dans cet ordre. L'administration centrale fournit moins de $18 \%$ du financement de la gestion du système. La diversité des acteurs de la gestion des aires protégées crée un système de gouvernance dynamique et varié, les différents intervenants contribuant chacun au débat pour affiner constamment les pratiques de gestion. 